\title{
WEIGHTED VERSION OF GENERAL INTEGRAL FORMULA OF EULER TYPE
}

\author{
S. KOVAČ AND J. PEČARIĆ
}

Abstract. The weighted generalization of the integral formula with $m$ nodes is introduced, and some sharp and the best possible inequalities for the functions whose higher order derivatives belong to $L_{p}$ spaces are given. Specially, the general one-point integral formula is established. Special cases of the well known weights are considered and generalizations of the Gaussian quadrature formulae with one node are obtained.

Mathematics subject classification (2010): 26D15, 65D30, 65D32.

Keywords and phrases: harmonic polynomials, weighted integral formula, one-point formula, $w$ Appell sequences, $w$-harmonic sequences, weight functions, $L^{p}$ inequalities, Gauss rule, Euler identity.

\section{REFERENCES}

[1] A. Aglić Aljinović, Lu. Dedić, M. Matić, J. PeČArić, On weighted Euler harmonic identities with applications , Math. Inequal. Appl., 8, 2 (2005), 237-257.

[2] A. Aglić Aljinović, J. PeČArić, The weighted Euler identity, Math. Inequal. Appl., 8, 2 (2005), 207-221.

[3] LJ.Dedić, M. Matić, J. PeČARIĆ, On generalizations of Ostrowski inequality via some Euler-type identities, Math. Inequal. Appl., 3, 3 (2000), 337-353.

[4] S.S.DRAGOMIR, The generalized integration by parts formula for Appell sequences and related results, Communications of the Korean Mathematical Society, 19 (2004), 75-92.

[5] S. Kovač, J. PEČARIĆ, A. VuKelić, A generalization of general two-point formula with applications in numerical integration, Nonlinear Analysis Series A: Theory, Methods and Applications, 68 (2008), 2445-2463.

[6] V. I. KRYLOV, Approximate calculation of integrals, Macmillan, New York-London, 1962.

[7] M. Matić, J. PeČARIĆ, N. Ujević, Generalizations of weighted version of Ostrowski's inequality and some related results, J. of Inequal. Appl., 5 (2000), 639-666.

[8] J. PeČARIĆ, S. VARošAnec, Harmonic Polynomials and Generalization of Ostrowski Inequality with Applications in Numerical Integration, Nonlinear Analysis Series A: Theory, Methods and Applications, 47 (2001), 2365-2374. 